\title{
O problema do conteúdo da valoração do depoimento dos delatores diante do conceito de justa causa para o regular exercício da ação penal
}

The problem of the content of the recognition of the testimony of the informers towards the concept of just cause for the regular exercise of the criminal action

Walter Barbosa Bittar ${ }^{1}$

Doutor em Ciências Criminais pela PUCRS.

Professor da PUCPR.

walter@advocaciabittar.adv.br

http://lattes.cnpq.br/5530106073792888

(D) http://orcid.org/0000-0002-4036-7865

\begin{abstract}
Resumo: $\mathrm{O}$ artigo analisa os problemas conceituais quanto à natureza jurídica do instituto da delação premiada, bem como da justa causa, buscando estabelecer limites quanto à valoração do conteúdo da versão apresentada pelos delatores, com maior atenção ao valor probatório, na forma prevista no ordenamento jurídico brasileiro, observando se é possível abranger o conteúdo do que pode ser compreendido como justa causa admitida, ou não, como requisito legítimo para o exercício da ação penal. Para cumprir este objetivo, buscou-se estabelecer requisitos de existência e validade para o início de um procedimento persecutório penal, destacando aspectos político criminais que terminam por influenciar a conclusão dos contornos inerentes ao objeto da análise do presente estudo.
\end{abstract}

Palavras-chave: Justa Causa; Condição da Ação; Delação Premiada; Valor Probatório.

1 Doutor em Ciências Criminais pela Pontifícia Universidade Católica do Rio Grande do Sul (Bolsista CAPES). Mestre em Direito pela Pontifícia Universidade Católica do Paraná. Pós graduado em Processo Penal pela Pontifícia Universidade Católica do Paraná. Membro da Associação Internacional de Direito Penal (AIDP). Atualmente é professor da graduação e da pós-graduação da Pontifícia Universidade Católica do Paraná, professor da pós graduação lato sensu em Direito e Processo Penal da Universidade Estadual de Londrina/PR, professor da Escola Superior da Magistratura do Estado do Paraná, unidade Londrina/PR. 
ABSTRACT: This article analyzes the conceptual problems regarding the legal nature of the plea bargaining and the just cause, seeking to establish limits regarding the recognition of the content of the version presented by the informers, with greater attention to the probative value, as seen in the Brazilian legal system, seeking if it is possible to include the content of what can be understood as accepted just cause, or not, as a legitimate requirement for the criminal action procedure. To fulfill this objective, we sought to establish existence and validity requirements for the beginning of a valid criminal prosecution procedure, highlighting the criminal political aspects that end up influencing in the conclusion of the inherent contours of the object of the analysis of the present study.

Kerwords: Just Cause; Condition of the Action; Plea Bargaining; Probative Value.

SUMÁRIO: Introdução; 1. O cenário e os particulares problemas da delação premiada no ordenamento brasileiro; 2. Compreensão do conceito de justa causa no direito processual penal pátrio; 3. A delação premiada e o seu valor probatório no recebimento da denúncia; Considerações Finais; Referências.

\section{INTRODUÇÃO}

Dentro da proporção tomada pelo uso do instituto da delação premiada no Brasil, com destacada presença das variantes exibidas pelos delatores nas investigações e processos criminais desencadeados e desenvolvidos - justamente - a partir da versão apresentada em desfavor dos delatados, principalmente a partir da dimensão tomada pelos procedimentos persecutórios penais iniciados pela chamada "Operação Lava Jato”,

2 A Operação Lava Jato, inquérito 3989/DF, é considerada a maior investigação de corrupção e lavagem de dinheiro do Brasil, estima-se que a quantidade de recursos desviados dos cofres da maior estatal do país envolvida no esquema, a Petrobrás, é estimada em bilhões de reais. A operação recebeu tal nome vez que as investigações levaram a uma rede de postos de combustíveis e lava a jato que movimentavam recursos ilícitos de uma das organizações criminosas investigadas. MPF. Entenda o caso. Disponível em: <http://lavajato.mpf. mp.br/entenda-o-caso>. Acesso em: $16 \mathrm{dez} 2016$. 
perante a previsão do art. 395 , III, do $\mathrm{CPP}^{3}$, instiga retornar ao conceito de justa causa para a ação penal, não só em face da ambiguidade da expressão $0^{4}$ e as diferentes abordagens a partir de então $0^{5}$, quanto a sua natureza jurídica, bem como de sua função, entre outras, de atuar como proteção contra eventuais abusos do poder de acusar ${ }^{6}$, em confronto com os filtros próprios ao início do procedimento persecutório penal.

Não bastassem os problemas inerentes à questão conceitual e delimitação da justa causa, aliam-se a estes aspectos extremamente polêmicos, a partir da introdução no ordenamento jurídico brasileiro, da figura incômoda da delação premiada ${ }^{7}$ como meio de obtenção de prova $^{8}$, quando esta também possui inúmeras dúvidas quanto a sua na-

3 Art. 395. A denúncia ou queixa será rejeitada quando: [...] III - faltar justa causa para o exercício da ação penal.

4 ASSIS MOURA, Maria Thereza Rocha de. Justa causa para a ação penal, Doutrina e jurisprudência. São Paulo: Revista dos Tribunais, 2001, p. 97-100.

5 Vale destacar que Afranio Silva Jardim, em face da redação do art. 395, III do CPP, mudou sua posição sobre o tema da justa causa, por entender que esta já não seria mais a quarta condição para o regular exercício da ação, como já havia sustentado anteriormente. Direito processual penal, $4^{\mathrm{a}}$ ed., Rio de Janeiro: Forense, 1992, p. 140-148. Atualmente este autor esclarece que a justa causa pressupõe acusação de uma conduta típica, em tese. Trata-se de uma questão de direito, diferente da existência ou não de suporte probatório mínimo de tudo o que esteja narrado na acusação, sugerindo o reconhecimento de outra categoria no processo penal condenatório, sob o nome de "pressuposto de legitimação do processo penal condenatório", que seria, assim, a natureza jurídica da justa causa, referida no art. 395, III, do CPP: JARDIM, Afranio Silva; AMORIM, Pierre Souto Maior Coutinho de. Direito processual penal: estudos e pareceres, $14^{\mathrm{a}}$ ed., Salvador: Juspodivm, 2016, p. 584.

6 LOPES JR., Aury. Direito processual penal. $12^{\mathrm{a}}$ ed., $2^{\mathrm{a}}$ tiragem. São Paulo: Saraiva, 2015, p. 194.

7 Dentre as críticas mais comuns destacadas pela doutrina podem ser observados os problemas próprios do modelo de justiça negociada, inerente a delação premiada, face a sua discricionariedade de uso por parte do Ministério Público, passando pela desvirtuação do contraditório, bem como as ameaças ao processo penal com núcleo acusatório: LOPES JR., Aury. Introdução crítica ao processo penal, $5^{\text {a }}$ ed., 2010, p. 137.

8 Embora a terminologia meio de obtenção de prova não seja normalmente utilizada, faz-se tal assertiva no intuito de ressaltar a distinção dos meios de prova, por não se tratar a delação de uma fonte de convencimento, mas por se prestar a obter do delator declarações dotadas de atitudes probatórias. Sobre a distinção entre meios de prova e meio de obtenção de prova veja-se: BADARÓ, Gustavo H. Ônus da prova no processo penal. São Paulo: Revista dos 
tureza jurídica e aos efeitos produzidos seja no direito processual, seja no direito material, bem como pelo fato de que a doutrina e a jurisprudência sobre o tema ainda não sejam expressivas sobre a exata valoração de seu conteúdo?.

Note-se que, assim como a justa causa, a delação premiada sempre suscitou críticas doutrinárias ${ }^{10}$, seja no que diz respeito à ausência de regulamentação legal, argumentação enfraquecida com o advento da Lei 12.850/2013, ou a própria utilização do instituto como instrumento legítimo para a investigação criminal, mormente no momento em que se identifica no ordenamento jurídico pátrio a nítida contrariedade do legislador ao indivíduo delator, por vezes, prevendo o agravamento e a causa de aumento de pena da sanção penal pela constatação do agir movido pela traição. ${ }^{11}$

Por outro lado, as dificuldades causadas a partir da introdução de um instituto estranho à estrutura da legislação pátria ainda não pode ser mensurada com precisão. Entretanto, um problema objetivo que precisa ser enfrentado é que, além da inexatidão conceitual dos elementos que permitem situar qual é o contexto de justa causa referido pela legislação brasileira, pouca atenção é dada para o conteúdo da versão do delator e a sua identificação, ou não, como um elemento apto para viabilizar uma ação penal e, em tal caso, resta-se inserido no que se configura uma justa causa para o exercício regular do direito de ação penal.

Dessa forma, e tendo ciência que o exame das condições para o regular exercício da ação passa pelo conceito de justa causa, consciente

Tribunais, 2003, p. 165; DEZEM, Guilherme M. Curso de processo penal. São Paulo: Revista dos Tribunais, 2015, p. 388 e ss.

9 Pontual é a crítica de Frederico Valdez Pereira ao destacar que o sistema acusatório de processo penal é ameaçado face a própria estrutura da uso de delatores (o autor prefere a expressão colaboradores), pois a sedução do prêmio como troca pela diminuição (ou extinção) da punição reforça a acusação, fornecendo-lhe mais um instrumento de persuasão, estimulando o indivíduo a renunciar o direito ao silêncio e a depor contra os cúmplices. PEREIRA, Frederico V. Compatibilização constitucional da colaboração premiada. Revista dos Tribunais, São Paulo, v. 929, 2013, p. 327.

10 Ver, por exemplo: BITTAR, Walter Barbosa. Delação premiada. $2^{\mathrm{a}}$ ed. Rio de Janeiro: Lumen Juris, 2011, p. 179-183.

11 Como, por exemplo, a agravante do art. 61, alínea "c" e a qualificadora do art. $121, \S 2^{\circ}$, IV, todos do Código Penal brasileiro. 
de que o norte para a formação do juízo de admissibilidade parte do pressuposto de que as afirmações que embasam um pedido condenatório pressupõem a veracidade das afirmações do fato, diante das peculiaridades do conteúdo de uma delação que possa ser considerada válida, e até mesmo minimamente confiável, para invocar legitimamente a tutela jurisdicional, o presente trabalho pretende destacar as questões polêmicas surgidas a partir deste cenário, focando se é possível identificar a versão do delator com o conceito de justa causa, referido na legislação pátria, para o início da persecução penal.

\section{O CENÁRIO E OS PARTICULARES PROBLEMAS DA DELAÇÃo PREMIADA NO ORDENAMENTO BRASILEIRO}

Observando-se o período anterior à Lei $12.850 / 13$, tem-se que a legislação sobre o tema tinha como referencial apenas normas de Direito material introduzidas sem critério (em especial sem qualquer preocupação com os aspectos processuais) em diversas legislações, inclusive não especificamente penais (caso da Lei 10.149/00), estas promulgadas de forma esparsa e distribuídas sem qualquer critério político criminal aparente, em diferentes legislações ${ }^{12}$, em que pese a jurisprudência do país tenha recepcionado bem a novidade. ${ }^{13}$

Importante esclarecer que, embora permaneça discussão quanto à identidade (ou não) entre os termos colaboração premiada e delação premiada (e se é um instituto de direito material ou processual), mesmo após a promulgação da Lei $12.850 / 13$, o presente artigo utilizará indiscriminadamente ambas as expressões com o mesmo sentido, compreendendo-as como termos sinônimos ${ }^{14}$, em sentido semelhante àquele adotado pela doutrina italiana que utiliza os termos colabora-

12 Lei 8.072/90; Lei 9.034/95; Lei 9.080/95; Lei 9.269/96; Lei 9.613/98; Lei 9.807/99; Lei 10.149/00; Lei 11.343/06.

13 A título de exemplo e não exaustivamente, veja-se as seguintes decisões: HC 75261, J. 24.jun.97, rel. Min. Octavio Galotti; RESP 418341, j. 26.maio.03, rel. Min. Felix Fischer; HC 33.833/PE, j. 19.ago.04, rel. Min. Gilson Dipp.

14 Em sentido oposto, admitindo divergência entre as expressões: LIMA, Renato Brasileiro de. Legislação Criminal Especial Comentada. $3^{\mathrm{a}}$. ed. Salvador: JusPODIVM, 2015, p. 525. 
ção, arrependidos (pentiti) e até mesmo delação, quando aborda o tema quanto à resposta punitiva premial ${ }^{15}$, bem como reconhecendo que, no Brasil, não houve a revogação de nenhuma outra norma já promulgada sobre o tema. ${ }^{16}$

Mas fato é que a introdução da delação premiada em nosso ordenamento jurídico, alheia a criação de normas procedimentais, deixou a natureza jurídica do prêmio oferecido ao delator identificada como uma causa de liberação de pena, tema, ironicamente, carente de estudos mais aprofundados, cujo âmbito de incidência resta circunscrito aos comportamentos pós-delitivos positivos ${ }^{17}$, mais especificamente o direito premial, em que está situada a delação premiada.

15 Como por exemplo é possível perceber consultando algumas obras sobre o tema: RUGGIERO, Rosa Anna. L'atendibilità delle dichiarazoni dei collaboratori di giustizia nella chiamata in correità, Torino: G. Giappichelli, 2012, p. 17 e notas de rodapé 40 e 41. RIVA, Carlos Ruga. Il premio pela la collaborazione processuale, Milano: Giuffrè, 2002, p. 12-26. Riva cita ainda a expressão delação (delazione) mencionada pela Procuradoria Geral quanto ao fomento de delações, bem como da palavra "pentitismo" (fenômeno do arrependimento em tradução livre e ampla) e colaborador (collaboratore), para destacar a discussão sobre a ética da delação e o uso que se dá para estas terminologias. Op. Cit., p. 543.

16 A questão é que o legislador não revogou o texto dos arts. 13 e 14 da Lei 9.087/99, que ampliou para toda a legislação pátria a possibilidade de perdão judicial, sem nenhuma vinculação ao tipo penal, nas hipóteses de colaboração e sem alteração de normas processuais, sendo legislação inerente ao Direito material. No mesmo sentido é a posição de Alberto Silva Franco, quanto a vigência desta legislação, ao afirmar que a Lei 9.807/99 "não estruturou novos tipos incriminadores sobre determinada matéria de proibição ou reformulou tipos pré-existentes, tendo apenas o duplo objetivo de estabelecer 'normas para a organização e manutenção de programas especiais de proteção a vítimas e testemunhas ameaçadas' e de dispor 'sobre a proteção de acusados ou condenados que tenham voluntariamente prestado efetiva colaboração à investigação policial e ao processo criminal'. Em segundo lugar, porque o texto dos arts. 13 e 14 da Lei 9.807/99 cria as hipóteses de perdão judicial e de causa redutora de pena, com ampla abrangência e sem nenhuma vinculação a determinados tipos legais": Crimes hediondos, $5^{\text {a }}$ ed., São Paulo: Revista dos Tribunais, 2005, p. 354

17 Sobre o tema, na doutrina pátria, veja-se: BITTAR, Walter Barbosa. A punibilidade no Direito Penal. São Paulo: Almedina, 2015. CARVALHO, Erika Mendes de. Punibilidade e delito. São Paulo: Revista dos Tribunais, 2008; RIOS, Rodrigo Sanchez. Extinção da punibilidade nos delitos econômicos. São Paulo: Revista dos Tribunais, 2003. 
Porém, com a vigência da Lei 12.850/13, e a consequente introdução de normas processuais, não apenas deixou a delação premiada de ser identificada somente como norma de direito material, como também ampliou-se no ordenamento jurídico brasileiro a restrição ao princípio da legalidade processual penal, este já anteriormente avariado com a promulgação da Lei 9.099/95, abrindo definitivamente as portas para o crescimento da oportunidade para a propositura da ação penal, negociando penas sem processo, concedendo benefícios para acusados e investigados, sem que existam na legislação brasileira referências específicas que permitam conhecer, com exatidão, quais são os limites proporcionais da concessão de beneplácitos, agora ofertados pela própria autoridade legal.

Neste cenário criou-se uma fissura no sistema processual penal pátrio, permitindo a elaboração de estratégias ardilosas (consequência do princípio processual da oportunidade e da possibilidade de barganhar com a acusação e a pena), face às vantagens propiciadas para uma parte colaboradora, em detrimento de outra que não aceite a colaboração, ou mesmo pleiteie a absolvição, ampliando a perspectiva de um processo penal como um jogo ${ }^{18}$, agora com estratégias para além do senso comum que, se bem organizadas e programadas, ainda que seus protagonistas não percebam, ou simplesmente desconheçam, abrem uma questão criminológica, que pode ser inicialmente alcunhada como "criminalidade programada", ou mesmo de "risco calculado"19.

A questão ora suscitada é que, ao permitir a concessão de prêmios ao acusado ou investigado que delata, fornecendo informações desconhecidas da autoridade, cujos limites não podem ser controla$\operatorname{dos}^{20}$ - chegando à constatação da existência de casos concretos em

18 CALAMANDREI, Piero. Il processo come giuoco. In: CARNELUTTI, Francesco. Scritti Giuridici in onore di Francesco Carnelutti. Padova: CEDAM, 1950. p. 485-511.

19 Sobre a ideia de criminalidade programada e risco calculado veja-se: BITTAR, Walter Barbosa. Delação premiada e a nova era do risco penal calculado. Disponível em: <http://emporiododireito.com.br/delacao-premiada-e-a-nova-era-do-risco-penal-calculado-por-walter-bittar/>. Acesso: em 2 jan. 2017.

20 Veja-se, por todos: GORRA, Daniel Gustavo. Resocialización de condenados. Buenos Aires: Astrea, 2013, p. 9 e ss. BAÑOS, Javier Ignacio. El fundamento de la pena. Buenos Aires: Ediar, 2011, p. 27 e ss. 
que houve devolução de valores e patrimônio de origem, no mínimo, suspeita ao delator ${ }^{21}$ - termina por inibir a função dissuasória, inerente ao aspecto preventivo geral da pena, produzindo um efeito inverso daquele teoricamente pretendido pela sanção criminal: incentivar a prática delitiva e obter benefícios.

Perceba-se que a teoria do regresso à legalidade, concebida a partir do momento em que o próprio Estado, por meio de seus agentes, fornece a oportunidade ao investigado ou processado criminalmente de voltar para à esfera da licitude do comportamento admitido pelo Direito, tem como base distintas formulações teóricas, identificadas pelo uso das expressões "regresso à legalidade", "reintegração na comunidade jurídica", "regresso do caminho do injusto ao caminho da justiça”, "expectativa de um comportamento fiel ao Direito" ${ }^{22}$, nomenclatura não exaustiva.

Além desse fator supramencionado, no caso do Brasil, já é possível identificar situações em que delatores contemplados com beneplácitos em processos criminais de vulto foram mais de uma vez beneficiados com prêmios em outros procedimentos persecutórios, diversos daquele que protagonizou o benefício da delação, em que o mesmo acusado, comprovando em nada ter sido afetado quanto ao efeito dissuasório da pena, ou mesmo de demonstração de temor aos efeitos da Lei vigente - novamente - recebeu tratamento privilegiado das autoridades legais, mesmo com a prática de injustos até mesmo mais graves daquele que originou o primeiro benefício. ${ }^{23}$

21 Já é possível observar em alguns procedimentos persecutórios penais e civis, em andamento, que se admitiu a devolução de bens e numerários de origem confessadamente ilegal ao delator, cuja restituição aos cofres do estado, ou mesmo reparação causada as vítimas do crime seria o caminho natural, afrontando o próprio fundamento da sanção criminal. Nestas delações homologadas fez-se constar que o delator terá parte dos valores objetos da persecução devolvidos como, por exemplo, pode ser conferido nos autos do Agravo de Instrumento $\mathrm{n}^{\mathrm{o}}$. 1361478-7, que tramitou na $5^{\mathrm{a}}$ Câmara Cível do Tribunal de Justiça do Estado do Paraná no ano de 2016.

22 PÉREZ, Laura Pozuelo. El desistimiento em la tentativa y la conducta post-delictiva. Valencia: Tirant lo Blanch, 2003, p. 72-73.

23 Alberto Youssef, personagem central da operação Lava Jato, já fora investigado, processado, preso e contemplado com o prêmio de sua liberdade, pela via da delação premiada, em 2003, em decorrência de sua atuação no mercado clan- 
Na hipótese permite-se a existência de um tentador atrativo, incrustado no próprio princípio da oportunidade, em face da delação, ao permitir que o investigado ou processado receba um estímulo singelo: ao invés de ser incitado a não cometer um ato ilícito sob ameaça de uma pena, ele seja provocado a correr os riscos inerentes à prática criminosa, invertendo a lógica da pretensa ressocialização inerente à prevenção especial ao abrir um incentivo - justamente - para a prática que o Estado, detentor do jus puniendi, deseja desestimular.

$\mathrm{Na}$ verdade, o legislador brasileiro, percebendo ou não, terminou por abrir caminho, por meio de legislação ampla e contrária à estrutura sistemática existente, oferecendo ao delinquente estímulo a correr riscos, ou seja, enfrentando a persecução criminal, arquitetando e projetando a gama de elementos de pretensa prova que poderão ser ofertadas as autoridades legais, buscando, por óbvio, os benefícios atrativos de uma condenação premiada (com diminuição ou mesmo isenção de pena, chegando até a possibilidade de obter o butim de seu crime).

Mas não é só. Ao permitir que o delator seja agraciado com a proteção de parte de seu patrimônio obtido ilicitamente, agora transformado em ativos lícitos, pois será reintegrado por determinação judicial, a pedido do próprio Ministério Público (com homologação judicial), ou seja, justamente a instituição legal, criada para, em tese, fiscalizar a lei ${ }^{24}$ e, no caso da ação penal pública, exercer a titularidade do jus persequendi, permite-se a reciclagem de ativos de origem ilícita conduta prevista como crime na legislação pátria. ${ }^{25}$

Ainda que se argumente, por um critério político-criminal, a existência de eventual fundamento para a liberação de pena, adotando

destino de dólares, após apuração de um dos maiores esquemas criminosos que já existir, o "Esquema CC5", também conhecido como caso Banestado. MPF. Caso Banestado. Disponível em: <http://lavajato.mpf.mp.br/atuacao-na-1a-instancia/investigacao/relacao-com-o-caso-banestado>. Acesso em: 8.dez. 2016.

É espantoso constatar que é possível documentar acordos já realizados entre delatores e o Ministério Público, alguns já homologados, isentando ou não requerendo a devolução total, de valores oriundos de práticas ilícitas e que pertençam ao investigado ou réu que colabore com os procedimentos persecutórios em curso. Disponível em: <http://emporiododireito.com.br/category/walter-bittar/>. Acesso em: 22 dez. 16.

Art. $1^{\circ}$ da Lei 9.613/98. 
uma filosofia utilitarista ou pragmática, admitindo que as informações oriundas de delatores auxiliem na tarefa da administração da Justiça ${ }^{26}$, tais motivos se afastam do logicamente razoável, pois o objetivo concreto seria evitar futuros delitos da mesma natureza ${ }^{27}$, algo que se mostra, no mínimo, um contrassenso.

Em oposição às ilações ora lançadas, sustenta-se que existem outros fundamentos para recepcionar nas legislações em geral, a possibilidade da oferta de benefícios aos investigados ou processados que, em tese (pois nunca será possível perceber, sinceramente, os reais objetivos de um delator que recebe beneplácitos sedutores), cumpram uma justificativa de diminuição de pena por exigência de prevenção geral ou especial, pois o próprio infrator atenderia exigências de algumas metas legais, como por exemplo o resgate ou a garantia de confiança no Direito. ${ }^{28}$

Porém, não se pode olvidar que, para argumentar a existência de fundamento a um instituto jurídico, não há que se considerar, isoladamente, a existência de motivos utilitários. Desse modo, o benefício com o qual será contemplado o delator, necessariamente, deve preencher o referencial mínimo de justificativa ou fundamento da pena, não podendo se afastar desta, ainda que a complexidade e sedução do instituto da delação premiada instigue a uma justificativa utilitária política, distante das regras e fundamentos do ordenamento jurídico, que não pode (e não precisa) ceder a pressões estranhas àquelas próprias da coerência mínima suportada pelo ordenamento jurídico.

Sempre que o legislador se afasta dos fundamentos da aplicação da sanção penal, oferecendo prêmios, ainda sem limite adequado no nosso ordenamento jurídico, o Estado passa a cumprir um papel ilegítimo, pois deixa de usar a sanção criminal como prevenção geral ou especial, criando e incrementando um sedutor incentivo para a prática criminosa planejada (que não se confunde com os conceitos conhecidos de organização criminosa), sem base teórica mínima quanto ao funda-

26 ESPANA, Elisa García. El premio a la colaboracíon com la justicia. Granada: Comares, 2006, p. 49.

27 PÉREZ, Laura Pozuelo. Op. Cit., p. 420.

28 Com mais detalhes: PÉREZ, Octavio Garcia. La punibilidad em el derecho penal, Pamplona: Aranzadi, 1997, p. 210. 
mento da aplicação de beneplácitos redutores, que podem até eliminar a possibilidade de aplicação de pena.

Nesse caso a delação passa a ser um instrumento de negociação planejada, sendo um perigoso mecanismo, que é justamente o de permitir aquele que deseja ofender um bem jurídico, fazê-lo com o devido planejamento avaliando eventual compensação de negociação de pena com o Ministério Público, pois a prática ilícita pode chegar até mesmo à espantosa hipótese de legalização do produto do crime, criando um risco calculado, abrindo espaço para a inauguração de um outro direito premial, ainda não explorado pela criminologia, mas que não se aproxima da ideia (ou conceito) de justa causa para iniciar um procedimento persecutório penal contra outrem.

Esta modalidade de direito premial cria uma relatividade extrema ao permitir (e abrir espaço) à prática de atividade ilícita, visando já nos atos preparatórios o cálculo da aplicação de pena que será perdoada, ou negociada, sem qualquer fundamento teórico mínimo (pelo menos que seja conhecido pelos pesquisadores atualmente), culminando na afirmação de que a pena não precisa de fundamento, muito menos de fins conhecidos ou legítimos, logo, indiferente e desprezível enquanto atividade praticada pelo Estado.

Outro ponto de reflexão deveras importante projeta-se sobre a questão das construções daquilo que o homem produz, como fator de responsabilidade pela necessidade de vivenciar, de forma autêntica, o que a natureza humana é capaz de construir.

Desse modo, tendo o Direito como referência de uma das criações humanas, esse risco calculado, cunhado a partir de um modelo de incentivo ao oferecimento de prêmios aos criminosos delatores, descortina uma farsa criminológica e, portanto, da ideia de justo, inerente ao conteúdo compreendido na expressão justa causa previsto na legislação processual pátria.

Ao permitir o indivíduo antever as possíveis consequências de uma persecução criminal, especialmente quando não se exige, validamente, que o comportamento contrário à Lei seja desestimulado, mesmo que se compreenda as versões apresentadas pelos delatores como algo vinculado ao utilitarismo, puro e simples, admite-se algo cujo conteúdo não pode ser mensurado em sua plenitude, em especial suas in- 
tenções e credibilidade, devendo ser calculado por critérios palpáveis e minimamente seguros, para que o seu conteúdo seja levado a sério. ${ }^{29}$

\section{Compreensão do CONCEITO de JUStA CAUSA No diREITO PROCESSUAL PENAL PÁTRIO}

Ressalvada a questão óbvia da dificuldade de estabelecer uma definição de justa causa, em especial pelo fato de que o justo constitui um valor ${ }^{30}$, faz-se necessário superar a adversidade para buscar sua natureza jurídica visando servir de referência, em especial a partir da opção do legislador pátrio em valer-se do termo como filtro para admissão, ou não, da acusação lastreada na versão apresentada pelo delator.

O primeiro ponto a ser enfrentado reside na identificação, ou não, da justa causa como condição autônoma para o exercício regular da ação penal. ${ }^{31}$

Como recorda Gustavo Badaró, a justa causa foi identificada como a necessidade de que a denúncia ou queixa descrevesse, em tese, um fato típico e seria enquadrável no revogado art. 43, caput, I, do CPP: faltaria justa causa para a ação penal, e a exordial deveria ser rejeitada, quando o fato narrado evidentemente não constituísse crime. No entanto, o conceito não era suficiente. ${ }^{32}$

Fato é que o caráter infamante do processo penal, como uma modalidade de pena, não permite admitir denúncias temerárias, sem conexão com a fase pré-processual. Assim, "a noção de justa causa evoluiu, então, de um conceito abstrato para uma ideia concreta, exi-

29 Em que pese a conclusão não seja especificamente sobre os problemas ético-morais da delação premiada, o raciocínio se refere às ilações de Ronald Dworkin em: DWORKING, Ronald. A raposa e o porco-espinho Justiça e Valor. São Paulo: Martins Fontes, 2014, p. 26 e ss.

30 ASSIS MOURA, Maria Thereza Rocha de. Op. cit., p. 97.

31 Houve quem sustentou ser a justa causa uma das condições da ação autônoma, não uma espécie distinta, por estar ligada à exigência de um interesse legítimo na instauração da ação, apto a condicionar a admissibilidade do julgamento do mérito, o próprio interesse de agir: TUCCI, Rogerio Lauria. Teoria do Direito Processual Penal: jurisdição, ação e processo penal, São Paulo: RT, 2002, p. 95.

32 BADARÓ, Gustavo H. Processo Penal, 4ª ed., São Paulo: RT, 2016, p. 171. 
gindo a existência de elementos de convicção que demonstrem a viabilidade da ação penal" ${ }^{3}$.

Nesse contexto a ideia de justa causa restou mais atrelada à existência de suporte probatório mínimo que deve lastrear qualquer acusação penal, vinculada à existência material de um crime e sua autoria, tendo sido identificada, inclusive, como uma das condições para o regular exercício do direito de ação que, se ausente, configuraria abuso trazido ao plano processual. ${ }^{34}$

O ainda vigente artigo 648, I, do Código de Processo Penal, que trata do habeas corpus, prevê como modalidade de coação ilegal a ausência da justa causa - com citação expressa ${ }^{35}$ - ampliando o conceito que, genericamente, implica em reconhecer a possibilidade de um ato ser atacado, quanto a sua ilegalidade, por uma coação considerada injusta (e com sentido de juízo de valor), sempre que se considere o ato sem supedâneo legal no ordenamento jurídico.

Talvez por força da redação da legislação suprarreferida, expressiva parte de doutrina brasileira ainda considera a justa causa como uma das condições da ação, não existindo, assim, consenso sobre se (e como), de fato, configura uma condição. ${ }^{36}$

Porém, com a nova redação do artigo 395 do Código de Processo Penal, incluído pela Lei 11.719/08, que substituiu o agora revogado artigo 43, ante à opção do legislador pátrio em incluir a justa causa em inciso diverso das condições para o exercício da ação penal, no que tange a rejeição da denúncia ou queixa ${ }^{37}$, o que estava limitado a doutrina e jurisprudência, em que pese a previsão do art. 648, I, do Código de Processo Penal, tornou-se matéria de lei, incluindo a justa causa como

33 Idem, ibidem.

34 JARDIM, Afrânio Silva. Direito Processual Penal, $4^{\mathrm{a}}$ ed., Rio de Janeiro: Forense, 192, p. 140.

35 Art. 648. A coação considerar-se-á ilegal: I - quando não houver justa causa.

36 Como por exemplo: PACELLI, Eugênio; FISCHER, Douglas. Comentários ao Código de Processo Penal e sua Jurisprudência, $8^{\mathrm{a}}$ ed., São Paulo: RT, 2016, p. 1532; DEZEM, Guilherme M. Curso de processo penal, São Paulo: RT, 2015, p. 176; LOPES JR., Aury. Direito Processual Penal, $12^{\mathrm{a}}$ ed., São Paulo: Saraiva, 2015, p. 193.

37 JARDIM, Afranio Silva. Direito Processual Penal, $14^{\mathrm{a}}$ ed., Salvador: Juspodivm, 2016, p. 582. 
matéria preliminar, mas não especificando se seria uma condição da ação, tampouco, seu significado ${ }^{38}$.

Neste ponto, insta recordar a antiga posição de Afrânio Silva Jardim em considerar a justa causa como uma quarta condição da ação $0^{39}$, atualmente alterada pelo autor, ao defender um novo conceito de justa causa, mas ainda considerando que nas ações penais condenatórias não é admissível uma acusação sem lastro probatório mínimo daquilo que está imputado na exordial processual. ${ }^{40}$

Em face da redação atual do art. 395 do Código de Processo Penal, em que o legislador inseriu a justa causa em inciso diverso das condições para o exercício da ação penal ${ }^{41}$, Afrânio Silva Jardim afasta a possibilidade de se colocar a justa causa como sinônimo de suporte probatório mínimo ${ }^{42}$ (que o autor ainda considera como condição para o exercício regular do direito de ação penal), concebendo-a como uma outra categoria no processo penal, sob o nome de pressuposto de legitimação do processo penal condenatório, para que este seja legitimamente instaurado, defendendo atualmente ser esta a natureza jurídica da justa causa, referida no art. 395, III, do Código. ${ }^{43}$

Mesmo com todas essas ressalvas, em virtude da citação expressa no artigo 648, I, do Código de Processo Penal, conforme ressalta Marcellus Polastri Lima, a justa causa vem sendo identificada como o próprio interesse de agir, e mesmo com as demais condições para o exercício do direito de ação justa, em virtude de que esta norma prevê a existência de coação ilegal quando não houver justa causa. ${ }^{4}{ }^{4}$

38 PACELLI, Eugenio. Curso de Processo Penal, 20ª Ed. São Paulo: Atlas, 2016, p. 118.

39 JARDIM, Afrânio Silva. Direito Processual Penal, $4^{\mathrm{a}}$ ed., Rio de Janeiro: Forense, 1992, p. 146.

40 JARDIM, Afrânio Silva. Direito Processual Penal: Estudos e Pareceres, $14^{\mathrm{a}}$ ed., Salvador: Juspodivm, 2016, p. 582.

41 Contra e entendendo que a redação do art. 395, face a Lei 11.719/08, deixou expressamente assentada a justa causa como condição da ação: PACELLI, Eugenio. Curso de Processo Penal, 20ª ed., São Paulo: Atlas, 2016, p.119.

42 Idem, ibidem.

43 Idem, p. 585.

44 LIMA, Marcellus P. Curso de Processo Penal, 8a ed., Brasília: Gazeta Jurídica, 2014, p. 190-191. 
Outro ponto a ser mencionado é que a falta de justa causa tem sido usada de modo muito abrangente, tendo em conta a especial natureza do processo penal, que não pode ser admitido como um processo injusto, dando uma dimensão muito ampla a expressão falta de justa causa, para designar uma série de situações comprometedoras da viabilidade do processo penal, servindo como um nome comum para as causas de rejeição da denúncia ou queixa, não a transformando em uma condição específica da ação ou de procedibilidade. ${ }^{45}$

Dessa forma, considerando ainda a previsão doa art. 395, do Código de Processo Penal ${ }^{46}$, afasta-se a possibilidade de ser a justa causa uma quarta condição da ação, mas deve ser reconhecido que não há cabimento para o exercício da ação penal sem um lastro probatório mínimo, mesmo sem expressa exigência legal.

Porém, a justa causa resta identificada como um requisito para o recebimento da denúncia ou queixa, desde que lastreada em lastro probatório mínimo, colhido na fase investigativa ou nas peças de informação (se encontra correspondência em inquérito ou peça de informação), independentemente de a denúncia narrar fato em tese atípico, ou descrever fato que não guarde ressonância com a prova colhida. ${ }^{47}$

Deve ainda ser observado como ressalta Maria Thereza Rocha de Assis Moura que em qualquer caso (atipicidade ou inexistência de nexo com a prova colhida) "haverá ilicitude e, mais do que isso, imoralidade. E tanto a doutrina como a jurisprudência entendem que faltará, na hipótese, justa causa para a ação penal" ${ }^{48}$.

Porém, conforme as exigências presentes no próprio Código de Processo Penal, diante da redação do art. 395, certo é que a justa causa, para a questão ora enfrentada, significa que há exigência ao menos de possibilidade de autoria conectada à existência de, pelo menos, uma prova (sem olvidar que delação não é prova, conforme especificado no

45 LIMA, Marcellus Polastri. Curso de Processo Penal, $8^{\text {a }}$ ed., Brasilia: Gazeta Jurídica, 2014, p. 192.

46 O próprio legislador tratou de separar e, assim, estabelecer diferença conceitual entre a justa causa (inciso II) e as condições da ação (inciso III), do art. 395, CPP.

47 ASSIS MOURA, Maria Thereza Rocha de. Op. cit., p. 222.

48 Idem, ibidem. 
item 3 infra), viabilizando o próprio projeto de uma ação penal viável, calcada em provas que deem plausibilidade ao pedido.

Em resumo, o conceito de justa causa está intimamente atrelado ao conceito de prova da materialidade delitiva, com indícios de autoria, existindo probabilidade ${ }^{49}$ da prática de um delito, requisitos que expressam, no caso concreto, o conceito de justa causa para o exercício da ação penal, como condição de garantia contra o ato abusivo de acusar.

A partir de um tal conceito de justa causa, insta observar quando, e se, a delação premiada ou, no caso concreto, a versão dos fatos apresentada pelo delator, insere-se no arsenal probatório mínimo para configurar a existência de justa causa para a ação penal, configurando, ou não, excesso do poder de acusar.

\section{A delaÇÃo PREMIAdA E O SEU VALOR PROBATÓRIO NO RECEBIMENTO DA DENÚNCIA}

Mesmo com sua previsão legal já sendo encontrada nas Ordenações Filipinas, em que já existia a possibilidade de perdão para alguns $\operatorname{casos}^{50}$, para os efeitos do presente trabalho, a delação premiada deve ser compreendida no direito brasileiro a partir de sua introdução na década de 1990 com a Lei dos Crimes Hediondos (art. $8^{\circ}$, parágrafo único, Lei 8.072/1990), posteriormente é prevista no art. $6^{\circ}$ da Lei 9.034/1995, também capitulada nos crimes contra o sistema financeiro nacional e nos crimes de sonegação fiscal, por força da Lei 9.080/1995 e ainda no crime de extorsão mediante sequestro (art. 159, $\S 4^{\circ}$ do Código Penal com redação dada pela Lei 9.269/1996), todas elas contemplando como prêmio ao delator a possibilidade de redução da pena de $1 / 3$ a $2 / 3$.

49 Conforme leciona Maria Thereza Rocha de Assis Moura “o juízo do possível conduz à suspeita, e é inaproveitável para uma acusação. Para que uma pessoa seja acusada da prática de infração penal, deve despontar não como possível, mas como provável, autor do delito" (Op. cit, p. 222).

50 PENTEADO, Jaques Camargo. Delação premiada. In: FARIA COSTA, José Francisco de; SILVA, Marco Antonio Marques (Coord.). Direito Penal especial, processo penal e direitos fundamentais. São Paulo: Quartier Latin, 2006, p. 643. 
Por sua vez, a Lei 9.613/1998 (dispõe sobre os crimes de lavagem ou ocultação de bens, direitos e valores) permitiu, além da redução de pena em patamar idêntico àqueles anteriormente previstos, a admissão de início do cumprimento da pena em regime aberto, a substituição por restritiva de direitos, podendo alcançar até mesmo o perdão judicial.

O instituto ganha maior extensão com o advento da Lei 9.807/1999 (Lei de Proteção à Vítima e à Testemunha), especialmente porque não vinculou o beneplácito legal a qualquer delito em específico, o que implicou assentir a sua aplicação a todo crime previsto na legislação pátria, bastando o preenchimento dos requisitos estipulados na aludida legislação ${ }^{51}$, situação que perdura até hoje, posto que esta legislação continua em vigor.

Na mesma esteira da política premial do âmbito penal, o legislador previu na Lei 10.149/2000 disposições legal com a pretensão de prevenir e reprimir infrações à ordem econômica, permitindo a celebração de acordo de leniência entre pessoas físicas e jurídicas autoras de infração à ordem econômica e à União, estipulando duas benesses legais de ordem penal e processual penal: suspensão do prazo prescricional (com impedimento de oferecimento da denúncia) ${ }^{52}$ e extinção da punibilidade. ${ }^{53}$ Em acréscimo, saliente-se que, recentemente, as Leis $12.529 / 11^{54}$

51 BITTAR, Walter Barbosa. Delação Premiada (Direito Estrangeiro, Doutrina e Jurisprudência). Rio de Janeiro: Lumen Juris, 2011, p. 146.

52 Sobre a impossibilidade do acordo de leniência constituir óbice ao manejo da ação penal em virtude da ausência de participação do Ministério Público na celebração do acordo veja-se: SOARES, Rafael Junior. Da impossibilidade do uso do acordo de leniência como forma de impedir o oferecimento de denúncia pelo Ministério Público. Boletim IBCCRIM. São Paulo, Out. 2010, p. 6-7. BITTAR, Walter Barbosa. Op cit., p. 152-153.

54 Prevê efeitos penais para o acordo de leniência, dispondo que: "Art. 87. Nos crimes contra a ordem econômica, tipificados na Lei no 8.137, de 27 de dezembro de 1990, e nos demais crimes diretamente relacionados à prática de cartel, tais como os tipificados na Lei no 8.666, de 21 de junho de 1993, e os tipificados no art. 288 do Decreto-Lei no 2.848, de 7 de dezembro de 1940 - Código Penal, a celebração de acordo de leniência, nos termos desta Lei, determina a suspensão do curso do prazo prescricional e impede o oferecimento da denúncia com relação ao agente beneficiário da leniência. Parágrafo único. Cumprido o acordo de leniência pelo agente, extingue-se automaticamente a punibilidade dos crimes a que se refere o caput deste artigo." 
e 12.846/2013 ${ }^{55}$ contemplaram novas disposições acerca do acordo de leniência, a primeira estabelecendo o Conselho Administrativo de Direito Econômico (CADE) como parte legítima para celebrar a avença, enquanto a segunda estipula a autoridade máxima de cada órgão ou entidade pública (art. 16, caput), afirmando que no âmbito da União o órgão competente é a Controladoria-Geral da União-CGU (art. 16, §10).

Em seguida, a Lei 11.343/2006 contemplou no art. 41 a permissão para redução de pena de $1 / 3$ a 2/3, olvidando-se de estipular qualquer autorização para a extinção da punibilidade, que implica em restrição à aplicação deste dispositivo, uma vez que não houve revogação da Lei 9.807/1999, de modo que, o preenchimento dos requisitos legais elencados neste diploma legal permitiria a aplicação de todos os prêmios nela estipulados, por se tratar de norma mais benéfica ao indivíduo. ${ }^{56}$

Finalmente, sobreveio a Lei 12.850/2013 que propiciou maior segurança aos envolvidos no acordo de colaboração premiada, mormente porque estabeleceu de modo mais preciso os prêmios ao colaborador, o procedimento para formalização do acordo, a contribuição exigida para viabilizar o prêmio, em síntese, introduziu regulamentação muito mais pormenorizada que os diplomas predecessores, além disso, implementou a possibilidade de outros benefícios legais como o não oferecimento da denúncia e a progressão de regime independentemente do cumprimento do requisito objetivo.

Mesmo com os evidentes avanços recepcionados pela Lei $12.850 / 13$, com destaque para o fato de ser a primeira legislação sobre o tema que tratou de prever um referencial mínimo de regras para aplicação do beneplácito, ficou a cargo da doutrina e da jurisprudência determinar a natureza jurídica da delação premiada e o seu valor probatório, em que pese o $\S 16$ do art. $4^{\circ}$ da Lei $n^{\circ} 12.850 / 13$ se limite a estabelecer que: "Nenhuma sentença condenatória será proferida com fundamento apenas nas declarações de agente colaborador".

55 Realizando análise comparativa entre o acordo de leniência e a colaboração premiada: NUCCI, Guilherme de Souza. Corrupção e anticorrupção. Rio de Janeiro: Forense, 2015, p. 175-188.

56 BITTAR, Walter Barbosa. Op cit., p. 158. 
Mas, para a compreensão do âmbito do tema é preciso definir a denominada pela Lei 12.850/13 "colaboração premiada", consistente em "instituto de Direito Penal que garante ao investigado, indiciado, acusado ou condenado, um prêmio, redução podendo chegar até a liberação da pena, pela sua confissão e ajuda nos procedimentos persecutórios penais, prestada de forma voluntária (isso quer dizer, sem qualquer tipo de coação)." 57

É certo que subsistem argumentos pró ${ }^{58}$ e contra $^{59}$ acerca da aplicação do instituto da delação ou colaboração premiada, invocandose normalmente questões éticas e morais como óbices intransponíveis para o Estado atuar mediante essa técnica investigativa na persecução penal, porém, não há dúvidas que encontra respaldo normativo no arcabouço jurídico pátrio e por consistir em norma favorável ao acusado deve ser aplicada quando presentes os requisitos legais. ${ }^{60}$

Feitas estas ponderações, resta ainda ter presente que a discussão acerca do valor probatório da delação premiada passa, necessariamente, pela definição a respeito das declarações do delator figurarem como fonte ou meios de prova, ou seja, se ministram indicações úteis sujeitas a comprovação ou se, por si só, servem à comprovação da verdade no processo.

Para estabelecer uma diferenciação deve ser observado que na distinção entre meios de prova e meios da sua obtenção, naqueles há

57 BITTAR, Walter Barbosa. Op cit, p. 5.

58 PINTO, Ronaldo Batista. A Colaboração Premiada da Lei no 12.850/2013. Revista Magister de Direito Penal e Processual Penal, nº 56, Out-Nov/2013, p. 24/29.

59 Criticando veementemente a postura do Estado se valer da cooperação de um delinquente pelo preço da sua impunidade para perseguir delitos cf.: ZAFFARONI, Raul Eugenio. Crime Organizado: uma categorização frustrada. Discursos sediciosos: crime, direito e sociedade, Rio de Janeiro: Revan, ano 1, v. 1, 1996, p. 59.

60 Nesse sentido: “apesar das restrições jurídicas e éticas feitas ao instituto da delação premiada, não se pode fugir à conclusão de que o direito premial avançou e muito na legislação penal comum e, atualmente, pode ser considerado quer como causa extintiva de punibilidade através do perdão judicial, quer como causa de diminuição de pena, em relação a qualquer figura típica desde que o colaborador ou delator reúna os requisitos exigíveis." (FRANCO, Alberto Silva [et al]. Crimes Hediondos. 7ª ed. São Paulo: RT, 2011, p. 528). 
um "conjunto de instrumentos aptos a demonstrar a realidade dos fatos relevantes para o processo" ${ }^{61}$ enquanto nestes a definição pode ser resumida enquanto ferramentas empregadas na investigação e ulterior recolha de meios de prova, sejam fatos ou coisas. ${ }^{62}$

De forma mais específica, pode ser considerado que meios de obtenção de prova servem como instrumentos utilizados pelas autoridades judiciárias para investigar e colher fontes de prova, não sendo instrumentos para demonstrar o thema probandi, constituindo instrumentos para recolher no processo esses instrumentos ${ }^{63}$, sendo, portanto, a delação premiada mero meio de obtenção de prova, reconhecido inclusive pela redação do art. $3^{\circ}$, da Lei 12.850/13.

De toda sorte, é preciso consignar que a delação premiada isolada é incapaz de viabilizar um decreto condenatório, mormente após o advento da Lei 12.850/13 que em seu art. $4^{\circ}$, §16 positivou a insuficiência da versão do acusado colaborador como critério exclusivo para respaldar uma condenação criminal, posição consagrada na doutrina ${ }^{64}$ e jurisprudência ${ }^{65}$ mesmo antes da promulgação da legislação supramencionada.

Nessa perspectiva, a doutrina alertava para a necessidade da denominada prova de corroboração ${ }^{66}$, vale dizer, como a delação pre-

61 SOARES, Paulo. Meios de obtenção de prova no âmbito das medidas cautelares e de polícia. Coimbra: Almedina, 2014, p. 120.

62 SOARES, Paulo. Op cit p. 120.

63 JESUS, Francisco Marcolino de. Os meios de obtenção da prova em processo penal. $2^{\text {a }}$ ed., Coimbra: Almedina, 2015, p. 179.

64 BITTAR, Walter Barbosa. Op Cit p. 188/194. No mesmo sentido: PEREIRA, Frederico Valdez. Valor Probatório da Colaboração Processual (Delação Premiada). In: NUCCI, Guilherme de Souza; MOURA, Maria Thereza Rocha de Assis. Doutrinas Essenciais - Processo Penal. v. III. São Paulo: RT, 2012, p. 578/579. Também antes do advento da nova legislação Tiago Cintra Essado sugere a atenção ao disposto no art. 197, CPP, regra que impõe a apreciação da confissão em confronto com os demais elementos aportados ao feito (ESSADO, Tiago C. Delação Premiada e Idoneidade Probatória. Revista Brasileira de Ciências Criminais, ano 21, vol. 101, mar-abr. 2013, São Paulo, p. 222).

65 BRASIL. Supremo Tribunal Federal. HC 94034, Relator(a): Min. CÁRMEN LÚCIA, Primeira Turma, julgado em 10/06/2008, DJe-167 DIVULG 04-092008 PUBLIC 05-09-2008 EMENT VOL-02331-01 PP-00208.

66 No direito italiano há regulamentação específica acerca da valoração das declarações do corréu: “Art. 192 Valutazione della prova (...) 3. Le dichia- 
miada não legitima, isoladamente, a condenação dos delatados, impõese a obtenção da prova de corroboração ${ }^{67}$, consistente em elementos que permitam concluir pela veracidade da versão apresentada pelo acusado delator.

Com efeito, a regra analisada constitui limitação negativa ao livre convencimento do julgador e, para que a delação premiada obtenha o status de prova, além de respeitar os preceitos legais e constitucionais, deve observar outros critérios, como por exemplo: 1) a credibilidade do declarante, pormeio de dados como sua personalidade, seu passado, sua relação com os acusados, o motivo da sua colaboração; 2) a confiabilidade intrínseca ou genérica da declaração auferida da sua seriedade, precisão, coerência, constância e espontaneidade; 3) a existência e consistência das declarações com o confronto das demais provas, ou seja, atesta-se a confiabilidade extrínseca ou específica da declaração. ${ }^{68}$

Em outra vertente, seria possível observar ser a delação premiada uma modalidade de prova por indícios ${ }^{69}$ quando combinada com

razioni rese dal coimputato del medesimo reato o da persona imputata in un procedimento connesso a norma dell'articolo 12 sono valutate unitamente agli altri elementi di prova che ne confermano l'attendibilità.” (ITÁLIA. Codice di Procedura Penale. Disponível em <http://www.polpenuil.it/attachments/048_codice_di_procedura_penale.pdf $>$. Acesso em: 30 ago. 2016).

67 “(...) la declaración incriminatoria del coimputado carece de toda consistencia como prueba de cargo, cuando, siendo única, no resulta minimamente corroborada por otra u otras pruebas (...) Se exige, em consecuencia, a partir de ese momento, para que la declaración de un coimputado pueda desvirtuar esse derecho fundamental a la presunción de inocencia y, en consecuencia, fundar una condena, que exista una mínima corroboración de las declaraciones de los coimputados cuando estás son las únicas pruebas de cargo em las que se basa la Sentencia condenatória." (MARTINEZ GALINDO, Gema. Valor probatorio de declaraciones de coimputados [Comentário de jurisprudência] La ley penal: revista de derecho penal, procesal y penitenciario. n. 7, v. 1, 2004. p. 69).

68 Critérios fixados pela Corte de Cassação Italiana. Sobre isso, ver: BITTAR, Walter Barbosa. Op cit, p. 196.

69 A doutrina adverte que para afirmar a existência de indícios com fins probatórios, alguns elementos são necessários: 1) Certeza do fato indiciante; 2) Proposição geral fornecida pela lógica ou pela experiência; 3 ) Relação de causalidade entre o fato indicador e o fato indicado. Cumpridos os três itens ora mencionados, é possível afirmar que, no processo, existem indícios do fato 
outros elementos (o que, solitariamente, não é) e, a partir desta ilação, considerá-la um meio de prova. Mesmo assim, esses indícios não devem ser isolados, mas devem ser múltiplos e surgirem relacionados com algo, além do mais o fato indício deve estar totalmente demonstrado, bem como entre o fato indício (a delação) e o fato consequência (o fato presumido) deve existir um nexo preciso e direto. ${ }^{70}$

Não se pode olvidar também que o concurso de indícios, para ser considerado como prova, deve ser completo em sentido amplo, e ainda, não estar em desacordo com o conjunto, estabelecendo qual é a sua causa. ${ }^{71}$

Desse modo, especificamente quanto ao valor probatório da delação premiada deve ser destacado, como recorda Stefanie Mehrens, que há evidentes dificuldades quanto à valoração das declarações dos delatores, pois estão sob o âmbito do extremo interesse pessoal e o manifesto estímulo às colaborações, com prêmios sedutores ao criminoso, confere a estas declarações um traço não adequado de verdade, devendo o juiz, em cada caso, na valoração do meio de prova, sopesar profundamente os motivos que impeliram o agente a colaborar. ${ }^{72}$

Todas essas circunstâncias permitem afirmar que a prova oriunda da delação possui uma natureza meramente indiciária (não podendo ser valorada para além disso), mas desde que combinada com outros elementos de convicção presentes na investigação, ou produzidas durante a instrução processual. Além do mais, os indícios devem concordar entre si, não sendo a versão isolada do delator mais do

investigado. Porém, para que seja considerado meio de prova, não poderão estar viciados de nulidade (ASSIS MOURA, Maria Thereza Rocha de. A prova por indícios no processo penal, Reimpressão, Rio de Janeiro: Lumen Juris, 2009, p. 89 e ss.).

70 ARMENTA DEU, Teresa. Lecciones de derecho procesal penal. $9^{\mathrm{a}}$ ed.. Madrid: Marcial Pons, 2016, p. 300. Deve ser observado que esta autora não faz estas colocações especificamente quanto a delação premiada mas, sim, quanto a prova por indícios.

71 ASSIS MOURA, Maria Thereza Rocha de. A prova por indícios no processo penal (Reimpressão), Rio de Janeiro, Lumen Juris, 2009, p. 99.

72 MEHRENS, Stefanie. La disciplina tedesca sui collaboratori di giustizia per i reati commessi in forma organizzata. In: MILITELLO, Vicenzo, et. al. Il crimine organizzato como fenomeno transnazionale. Milão: Giuffré, 2000, p. 341. 
que uma hipótese isolada que nada configura, ficando completamente afastada da ideia de justa causa.

\section{CONSIDERAÇõES FINAIS}

É certo que o conceito de justa causa não é imune a divergências no âmbito doutrinário e jurisprudencial, mas inexistem dúvidas de que a delação - sem que exista nenhum outro respaldo probatório - não legitima a inauguração do processo penal em desfavor de qualquer pessoa, especialmente ao considerar a inegável existência de penas processuais. ${ }^{73}$

Porém, na hipótese específica da delação premiada, enquanto elemento suficiente a inaugurar o processo criminal, deve ser indagado se a exordial processual é oferecida tão somente com base na versão apresentada pelo delator e, se positiva a resposta, resta clara a inexistência de justa causa, visto que no caso não existe prova, sequer indiciária, cuja procedência está crivada de credibilidade (em razão de sua procedência e dos motivos pelos quais o criminoso delator os sustenta), que sequer o princípio do in dubio pro societate lhe socorre.

Da mesma forma, para que se analise a justa causa, vale dizer, a justa razão ou aquela suficiente para a instauração da ação penal, não se poderá fazer apenas uma análise abstrata, mas, sim, em elementos que demonstrem a existência de fato e de Direito, a partir do caso concreto, o que resta impossível a partir da análise da versão apresentada pelo delator, quando esta é a única que ampara o recebimento da denúncia e não é admitida como prova.

Finalmente, a insegurança dos conceitos de delação premiada e justa causa, ainda mais perante uma legislação incompleta e ampla, em

73 "O desencadear do caso penal deve ser permeado por um grau de responsabilidade de seu prolator, a refletir a serenidade do Estado ao qual se encontra vinculado. A dignidade da opinio delicti ou o púlpito ministerial não devem ser palco de vinditas ou perseguições pessoais. Ou submissão de pessoas aos vexames de uma apuração quando não haja uma garantia verossímil e racional de que haverá, ao menos, uma perspectiva razoável de procedência do pedido." (OLIVEIRA, André Luis Tabosa de. A acusação responsável como direito fundamental. Rio de Janeiro: Lumen Juris, 2015, p. 182). 
que se deseja uma interpretação muito mais teleológica do que sistemática, termina por impor o reconhecimento de que não há consonância entre o conceito (e até mesmo a ideia) de justa causa exigido para o início do processo penal, quando se tem como única referência a versão apresentada por um delator, cujos interesses e objetivos se afastam do conceito de justo inerente ao início de uma ação penal válida.

\section{REFERÊNCIAS}

ARMENTA DEU, Teresa. Lecciones de derecho procesal penal. 9a ed., Madrid: Marcial Pons, 2016.

ASSIS MOURA, Maria Thereza Rocha de. Justa causa para a ação penal, Doutrina e jurisprudência. São Paulo: RT, 2001.

ASSIS MOURA, Maria Thereza Rocha de. A prova por indícios no processo penal, Reimpressão, Rio de Janeiro: RT, 2009.

BADARÓ, Gustavo Henrique Righi Ivahy. Ônus da prova no processo penal. São Paulo: RT, 2003.

BADARÓ, Gustavo Henrique Righi Ivahy. Processo Penal. $4^{\mathrm{a}}$ ed., São Paulo: RT, 2016.

BAÑOS, Javier Ignacio. El fundamento de la pena. Buenos Aires: Ediar, 2011.

BITTAR, Walter Barbosa. Delação Premiada (Direito Estrangeiro, Doutrina e Jurisprudência). Rio de Janeiro: Lumen Juris, 2011.

BITTAR, Walter Barbosa. A punibilidade no Direito Penal. São Paulo: Almedina, 2015.

BITTAR, Walter Barbosa. Delação premiada e a nova era do risco penal calculado. Disponível em: <http://emporiododireito.com.br/delacao-premiada-e-a-novaera-do-risco-penal-calculado-por-walter-bittar/>. Acesso, em 2 jan. 2017.

CALAMANDREI, Piero. Il processo come giuoco. In: CARNELUTTI, Francesco. Scritti Giuridici in onore di Francesco Carnelutti. Padova: CEDAM, 1950. p. 485511.

CARVALHO, Erika Mendes de. Punibilidade e delito. São Paulo: Revista dos Tribunais, 2008.

CUNHA, Rogerio Sanches; MARQUES, Ivan Luís. Processo penal I: investigação preliminar, ação penal, ação civil “ex delicto". São Paulo : Saraiva, 2012. 
DEZEM, Guilherme Madeira. Curso de processo penal. São Paulo: Revista dos Tribunais, 2015.

DWORKIN, Ronald. A raposa e o porco-espinho Justiça e Valor. São Paulo: Martins Fontes, 2014.

ESPAÑA, Elisa García. El premio a la colaboracíon com la justicia. Granada: Comares, 2006.

ESSADO, Tiago C. Delação Premiada e Idoneidade Probatória. Revista Brasileira de Ciências Criminais, São Paulo, ano 21, vol. 101, mar-abr. 2013.

FRANCO, Alberto Silva [et al]. Crimes Hediondos. $7^{\text {a }}$. ed. São Paulo: Revista dos Tribunais, 2011.

GORRA, Daniel Gustavo. Resocialización de condenados. Buenos Aires: Astrea, 2013.

JARDIM, Afrânio Silva; AMORIM, Pierre Souto Maior Coutinho de. Direito processual penal: estudos e pareceres, 14 ${ }^{\mathrm{a}}$ ed., Salvador: Juspodivm, 2016.

JARDIM, Afrânio Silva. Direito processual penal, $4^{\mathrm{a}}$ ed., Rio de Janeiro: Forense, 1992.

JESUS, Francisco Marcolino de. Os meios de obtenção da prova em processo penal. $2^{a}$ ed., Coimbra: Almedina, 2015.

LIMA, Marcellus Polastri. Curso de Processo Penal, 8a ed., Brasília: Gazeta Jurídica, 2014.

LOPES JR., Aury. Direito processual penal. $12^{\mathrm{a}}$ ed., $2^{\mathrm{a}}$ tiragem, São Paulo: Saraiva, 2015.

LOPES JR, Aury. Introdução Crítica ao Processo Penal. $5^{\mathrm{a}}$ edição, 2010.

MARTINEZ GALINDO, Gema. Valor probatorio de declaraciones de coimputados [Comentário de jurisprudência] La ley penal: revista de derecho penal, procesal y penitenciario. n. 7, v. 1, 2004.

MEHRENS, Stefanie. La disciplina tedesca sui collaboratori di giustizia per i reati commessi in forma organizzata. In: MILITELLO, Vicenzo, et. al. Il crimine organizzato como fenomeno transnazionale. Milão: Giuffré, 2000.

NUCCI, Guilherme de Souza. Corrupção e anticorrupção. Rio de Janeiro: Forense, 2015.

OLIVEIRA, André Luis Tabosa de. A acusação responsável como direito fundamental. Rio de Janeiro: Lumen Juris, 2015. 
OLIVEIRA, Eugênio Pacelli de. Curso de Processo Penal. $20^{\text {a }}$ Ed. São Paulo: Atlas, 2016.

PACELLI, Eugenio. FISCHER, Douglas. Comentários ao Código de Processo Penal e sua Jurisprudência, $8^{\mathrm{a}}$ ed., São Paulo: Atlas, 2016.

PENTEADO, Jaques Camardo. Delação premiada, in: FARIA COSTA, José Francisco de, SILVA, Marco Antonio Marques (Coord.). Direito Penal especial, processo penal e direitos fundamentais. São Paulo: Quartier Latin, 2006, p. 643.

PEREIRA, Frederico Valdez. Valor Probatório da Colaboração Processual (Delação Premiada). In: NUCCI, Guilherme de Souza; MOURA, Maria Thereza Rocha de Assis. Doutrinas Essenciais - Processo Penal. v. III. São Paulo: RT, 2012. PEREIRA, Frederico Valdez. Compatibilização Constitucional da Colaboração Premiada. Revista dos Tribunais. v. 929/2013.

PÉREZ, Laura Pozuelo. El desistimiento em la tentaiva y la conducta post-delictiva. Valencia: Tirant lo Blanch, 2003.

PÉREZ, Octavio Garcia. La punibilidad em el derecho penal. Pamplona: Aranzadi, 1997.

PINTO, Ronaldo Batista. A Colaboração Premiada da Lei no ${ }^{0} 12.850 / 2013$. Revista Magister de Direito Penal e Processual Penal, nº 56, Out-Nov/2013, p. 24/29.

RIOS, Rodrigo Sanchez. Extinção da punibilidade nos delitos econômicos. São Paulo: Revista dos Tribunais, 2003.

RIVA, Carlos Ruga. Il premio pela la collaborazione processuale, Milano: Giuffrè, 2002.

RUGGIERO, Rosa Anna. L'atendibilità delle dichiarazoni dei collaboratori di giustizia nella chiamata in correità, Torino: G. Giappichelli, 2012.

SOARES, Paulo. Meios de obtenção de prova no âmbito das medidas cautelares e de polícia. Coimbra: Almedina, 2014.

SOARES, Rafael Junior. Da impossibilidade do uso do acordo de leniência como forma de impedir o oferecimento de denúncia pelo Ministério Público. Boletim IBCCRIM. São Paulo, Out. 2010, p. 6-7.

ZAFFARONI, Raul Eugenio. Crime Organizado: uma categorização frustrada. Discursos sediciosos: crime, direito e sociedade, Rio de Janeiro: Revan, ano 1. V.1, 1996. 
Dados do processo editorial

(http://www.ibraspp.com.br/revista/index.php/RBDPP/about/editorialPolicies)

- Recebido em: 27/12/2016 Equipe editorial envolvida

- Controle preliminar e verificação de plágio: 28/12/2016

- Retorno rodada de correções 1: 12/01/2017

- Avaliação 1: 19/01/2017

- Avaliação 2: 22/01/2017

- Decisão editorial preliminar: 25/01/2017

- Retorno rodada de correções 2: 13/02/2017

- Decisão editorial final: 15/02/2017

\section{COMO CITAR ESTE ARTIGO:}

BITTAR, Walter B. O problema do conteúdo da valoração do depoimento dos delatores diante do conceito de justa causa para o regular exercício da ação penal. Revista Brasileira de Direito Processual Penal, Porto Alegre, vol. 3, n. 1, p. 225-251, jan./abr. 2017. https://doi.org/10.22197/rbdpp.v3i1.41

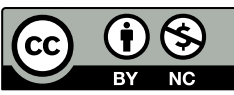

Esta obra está licenciada com uma Licença Creative Commons Atribuição-NãoComercial 4.0 Internacional. 